\title{
MEDIAÇÃO: UMA FERRAMENTA CONTRA A DESINFORMAÇÃO EM TEMPOS DE PÓS- VERDADE
}

\section{MEDIATION: A TOOL AGAINST DISINFORMATION IN POST-TRUTH TIMES}

\author{
Juliana Galvao de Matos Britoa \\ Luiz Tadeu Feitosab
}

\begin{abstract}
RESUMO
Objetivo: Em tempos de pós-verdade, as fake news ganham mais espaço e são responsáveis por mudanças importantes e prejudiciais na realidade do planeta. Fatos como as eleições de Donald Trump e o plebiscito do Brexit são considerados por analistas de política como o início da forma mais contundente de mudança de realidade a partir da difusão de notícias falsas. No Brasil, as eleições de 2018 também foram carregadas de desinformação. Fundamentado nos fenômenos da Ciência da Informação e da Comunicação, essa pesquisa analisa como o jornalismo se comporta nesse novo cenário. Metodologia: Análise de conteúdo e pesquisa bibliográfica com base nas teorias da comunicação e da informação. Resultados: Demonstra-se como a mediação realizada a partir dos sites de checagem de notícias são instrumentos para o combate a fake news, contra a disseminação de desinformação. Conclusões: Sites de checagem de notícias, como o Projeto Comprova, usam a mediação da informação e da comunicação como ferramenta para disseminar informações verídicas e detalhar como notícias falsas são construídas e facilmente divulgadas pelas redes sociais.
\end{abstract}

Descritores: Fake News. Pós-verdade. Comunicação. Informação. Jornalismo.

\section{INTRODUÇÃO}

Ao acessar as páginas de veículos de comunicação e seus perfis nas redes sociais, identifica-se como as Tecnologias da Informação e da Comunicação (TICs) transformaram não só a forma como se distribui a notícia, mas como ela é produzida e compartilhada. No século $X X$, as informações que

\footnotetext{
a Mestranda no Programa de Pós-Graduação em Ciência da Informação pela Universidade Federal do Ceará (UFC). E-mail: jumatosbrito@gmail.com.

b Doutor em Sociologia pela Universidade Federal do Ceará (UFC). Docente do Programa de Pós-graduação em Ciência da Informação e do Departamento de Ciências da Informação. Email: tadeu.feitosa62@ufc.br.
} 
deveriam ser publicadas em um veículo eram definidas a partir de fatos públicos, da decisão editorial dos jornais, que orientavam as condutas dos jornalistas, levando-se em conta os interesses das empresas (TRAQUINA, 2005). O poder da notícia e dos processos de informação estavam nas mãos dos jornalistas e das empresas de comunicação.

A prática comum desse caminhar informacional em forma de notícia tem as redações como cenário de tratamento da informação jornalística, onde o jornalista verifica a informação, mune-se de toda a técnica e ética jornalísticas para aferir e confrontar dados, escrever e revisar textos até que eles estejam prontos e, finalmente, editar o texto final e divulgar em seus veículos. Essa realidade começa a ser alterada com a chegada da Internet. A comunicação fica mais ágil, as informações fluem com mais rapidez e facilidade e a complexidade desses fluxos informacionais passa a alterar o tempo midiático e o espaço mediatizado da produção de notícias.

Com o advento das redes sociais e as abrangências desses fluxos de informação esse poder informacional dos jornais vem apresentando fissuras, porquanto o foco primordial dos jornais como emissores vem dividindo a atenção com as demandas informacionais advindas dessas redes. Os jornalistas e os veículos de comunicação oficiais não estão mais sós nessa definição do que deve ser a notícia, muito embora continuem a ter a vantagem e o poder presentes nas suas capacidades profissionais de produzirem notícias; no fato de a conduta jornalística ser dirigida por suas políticas editoriais; na relação ainda sólida entre os jornais, seus leitores e patrocinadores.

Mas esse poder da comunicação, no geral, e do jornalismo, em particular, está mais difuso porque agora fluxos complexos de informação são disseminados principalmente pelas redes sociais. O caminho para a definição do que é importante como informação jornalística ou não passa a se transformar, numa proporção ainda não calculada com precisão quanto aos efeitos caóticos da produção e difusão de notícias por pessoas que, nem sempre, possuem expertise para tal. Começa-se a identificar uma via de mão-dupla, as informações circulam das mídias para a comunidade e da comunidade para os veículos de comunicação. 
Em tempos de hiperconectividade, os ambientes e cenários mediacionais da informação, notadamente nos contextos da mídia, parecem lidar também com mediações culturais advindas do que se chama "cultura das mídias" (SANTAELLA, 2003). Assim, não basta apenas ter acesso à informação. É preciso ver e ser visto, participar e se movimentar pelas redes. A partir das TICs, as pessoas se tornaram produtoras e consumidoras de conteúdo dentro de uma "teia de significados" (GEERTZ, 1989) que se transforma a cada momento. Dentro dessa realidade, as redes sociais congregam uma legião de pessoas envolvidas na produção e no consumo de informação.

Atualmente, o papel das recepções é múltiplo. O cidadão que antes era apenas leitor do jornal, ouvinte de rádio ou telespectador da TV, hoje consome e produz notícias. E, muitas vezes, se vale dessa participação intensa nas redes para se tornar mais conhecido e ter um papel de destaque na sociedade.

O jornal, o portal de notícias, os veículos de comunicação de uma forma em geral deixam de ser apenas os emissores da informação e passam a olhar e a consumirem também o que o cidadão produz nas suas redes sociais. É uma situação em que se desconstrói o modelo linear e unidirecional tradicionalmente formado pelo modelo matemático de processo de comunicação, com foco no emissor, e muda-se o foco para o receptor e as muitas formas de recepção. Há, pois, uma construção não linear de sentidos, porquanto o consumidor e a audiência também são protagonistas desse processo - agora dialógico e não unidirecional - de informação.

O presente estudo - em curso numa pesquisa de mestrado em Ciência da Informação $(\mathrm{Cl})$ - aborda, grosso modo, linguagem, cultura, comunicação, mediação, apropriação e convergência tecnológica. A partir da epistemologia da comunicação e da informação, a pesquisa se debruça sobre os fenômenos e os efeitos dessa nova realidade, levantando a hipótese de que os estudos de mediação da informação desenvolvidos pela $\mathrm{Cl}$ são necessários para desenvolver ações mediacionais que analisem, apurem, verifiquem e apontem soluções para os processos de desinformação que esses cenários promovem; para a recorrente demanda dada nesses contextos para pós-verdade; e para a chamada infodemia, que passam a acontecer nesses contextos e situações 
problematizados acima.

\section{DESINFORMAÇÃO E PÓS-VERDADE}

O cenário problematizado na seção anterior vem provocando crises no jornalismo. A chamada cultura das convergências, definida por Henry Jenkins como mudanças culturais e tecnológicas "[...] no modo como as mídias circulam em nossa cultura" (JENKINS, 2009, p. 499) são o cenário principal das mudanças ocorridas no jornalismo. Para efeito deste trabalho, a abordagem é mais direcionada à movimentação caótica dos conteúdos pelas redes sociais e do poder que essa convergência deu aos consumidores, que passam a produzir informações e assumindo muitas vezes o papel que até bem pouco tempo só era destinado ao jornalismo.

É nesse contexto e submetido a uma espécie de chamamento das recepções às ações de emissão, possibilitadas pelas redes sociais, que surgem processos de desinformação e cenários propícios à pós-verdade, dois dos conceitos mais caros a este artigo.

Um cenário em que as pessoas dotadas de uma certa liberdade potencializada por inúmeros artefatos tecnológicos como smartphones, tablets e afins protagonizam fluxos intensos e complexos de informação e de compartilhamentos. Um cenário adverso aos princípios jornalísticos e que realça a já tão alardeada "crise do jornalismo". Principalmente em um tempo em que a crença pessoal se torna mais importante que a verdade. Tempos definidos como uma época de pós-verdade. E é justamente nesse cenário que surgem ferramentas no jornalismo que visam prestar um serviço de mediação à sociedade combatendo as notícias falsas, divulgadas principalmente com intuito político de desinformar e gerar vantagens a quem a espalha.

Um cenário que faz esta pesquisa defender a relação intrínseca entre a mediação da informação - fenômeno abordado pela Ciência da Informação com o jornalismo e a comunicação e que também realça o papel mediacional potencializado a partir da checagem de notícias, ferramenta amplamente utilizada pelos veículos de comunicação na atualidade para informar o que é verdade e/ou mentira para o leitor. 
Assim, a luta diária das práticas jornalísticas no combate à profusão de notícias falsas; o controverso papel das tecnologias da comunicação e informação e o mau uso das redes sociais no contexto atual; os estudos e aplicações ainda embrionários da mediação da informação no contexto do jornalismo e das redes sociais vêm mostrando nesta pesquisa que toda essa revolução na forma de consumir informação que vemos na atualidade não nos tornou uma sociedade mais justa. É preciso fazer uma análise crítica sobre as ações relacionadas diretamente à produção, circulação e apropriação da informação (ARAÚJO, 2018) e como isso se reflete hoje em dia. A crise de verdade que vivemos na atualidade e a forma como as informações são divulgadas e compartilhadas nos levou ainda a um problema real de epidemia da desinformação, que a OMS vem chamando de "infodemia".

\begin{abstract}
"A palavra infodemia se refere a um grande aumento no volume de informações associadas a um assunto específico, que podem se multiplicar exponencialmente em pouco tempo devido a um evento específico, como a pandemia atual. Nessa situação, surgem rumores e desinformação, além da manipulação de informações com intenção duvidosa. Na era da informação, esse fenômeno é amplificado pelas redes sociais e se alastra, como um vírus". (OPAS, 2020, p. 2)
\end{abstract}

Desinformação que deve ser entendida muito além da falta de informação. Em tempos de hiperconectividade, o conceito é relativo ao ato deliberado de induzir ao erro, uma forma de influenciar a opinião de um grupo de pessoas a partir da deturpação da verdade (PINHEIRO; BRITO, 2014). São notícias virais que são repassadas por redes sociais e aplicativos de notícias por leitores vorazes por estarem dentro desse ciclo de informação e que, muitas vezes, consomem informações que apenas reforçam suas crenças, sem questionar a veracidade de tal mensagem.

Essa nova forma de lidar com a informação e como compartilhamos notícias principalmente para reforçar um pensamento, um valor individual, é uma característica da pós-verdade. Pós-verdade descreve o método pelo qual as convicções pessoais e crenças passam a ser mais importantes que os fatos e as informações verídicas. As pessoas passam a ignorar a verdade e compartilham a mentira que é mais adequada aos interesses particulares.

O crescimento de modalidades de desinformação, com a ajuda de 
tecnologia como big data e algoritmos, por exemplo, está intrinsecamente relacionado ao fenômeno da pós-verdade (SCHNEIDER, 2019). E o que seria a desinformação? Ausência de informação? A informação manipulada? Vivemos "repletos de paradoxos pelos quais o excesso de informação caminha junto com as inúmeras possibilidades do "não acesso" ou de contato com sua antagonista: a desinformação" (SCHNEIDER, 2019, p. 129).

Os fatos recentes que marcaram o início desse olhar no mundo para os prejuízos causados pelas notícias falsas e como elas repercutem e mudam a realidade de um País foram as eleições de Donald Trump nos Estados Unidos em 2016 e o Brexit na Inglaterra. As duas campanhas foram guiadas pela guerra de informações falsas, usadas para influenciar a percepção sobre a realidade das pessoas. Essa artimanha gera confusão em relação aos fatos reais e alimenta um programa político (SANTAELLA, 2018).

A revista The Economist, em 10 de setembro de 2016, destacava em sua capa: "A arte da mentira: a política da pós-verdade na era das redes sociais" (A ART..., 2016). Os indícios que confirmavam a tese defendida pela reportagem estavam na eleição de Donald Trump e no Brexit. "Com a palavra 'pós-verdade', a revista pretendia colocar em evidência o cerne do que há de novo na política: a verdade já não é falseada ou contestada; tornou-se secundária. No passado, as mentiras políticas visavam criar uma visão enganosa do mundo. As mentiras de homens como Trump não funcionam assim. Seu intuito não é convencer, e sim reforçar preconceitos" (SANTAELLA, 2018, p. 34).

No Brasil, a eleição de Jair Bolsonaro em 2018 veio a reboque de muitas notícias falsas disseminadas pelas redes sociais, principalmente por aplicativos como o WhatsApp. Foi, portanto, a vez de o Brasil entrar com força na onda da desinformação para alterar uma realidade política. As notícias falsas afetam primordialmente a área da Política, como temos visto pelas principais mensagens que nos chegam pelas redes. Mas, em tempos de pandemia, a saúde também foi uma das áreas contaminadas pela desinformação, principalmente pela polarização política que o tema traz. Portanto, mesmo na saúde, é a política que faz com que essa área seja tão impactada pelas fake news, notícias fabricadas com o intuito de enganar, de gerar a desinformação. E 
o que seria atualmente a desinformação?

A novidade trazida pelo conceito é que hoje, com as novas tecnologias e a internet, as pessoas possuem muito mais condições de checar a veracidade dos fatos apresentados na mídia. É esse desinteresse pela verdade, 0 apego a preconceitos por parte de um grande contingente de pessoas que marca o fenômeno da pós-verdade, um elemento fundamental para se entender a realidade informacional contemporânea. (ARAÚJO, 2018, p. 45).

Estudos diversos mostram diferentes formas de desinformação. Do inglês misinformation (desinformação não deliberada), disinformation (desinformação deliberada) e deception (falta de informação ou auto-engano), esses fenômenos trazem verdades descontextualizadas ou uma narrativa mentirosa. (SCHNEIDER, 2019).

O que se pode inferir das discussões levadas a cabo sobre o tema é que a falsidade funciona em toda a sua potência propagadora porque as pessoas tendem a se recolher dentro das bolhas de seus preconceitos. Tornam-se, assim, presas fáceis de interesses dos quais não conseguem se dar conta. (SANTAELLA, 2018, p. 25).

Para a autora, é importante que a ciência entenda o que são as fake news, forma mais comuns de identificarmos a desinformação, para que o enfrentamento seja iniciado. As questões são complexas e vêm sendo estudadas com rigor pelas ciências sociais. Os estudos de Comunicação, os tratados sobre jornalismo contemporâneo e suas crises também contribuem com as reflexões sobre esses cenários caóticos que unem informação e desinformação, verdade e pós-verdade, profusão de informação e infodemia. Na pesquisa de mestrado em curso, o foco sobre a contribuição da $\mathrm{Cl}$ recai sobre os aspectos centrais da mediação da informação, conceito e teoria sintetizados na próxima seção como o fito de levantar chaves de leitura capazes de realçar nas ações de checagens de notícias as mediações que julgamos necessárias às práticas jornalísticas.

\section{MEDIAÇÃO DA INFORMAÇÃO}

No âmbito da "cultura das mídias" e da "cultura das convergências" os papéis de emissor e receptor vêm ora se invertendo, ora em diálogos caóticos 
no que concerne às difusões de informação. Os estudos de comunicação vêm atualizando suas pesquisas e reflexões sobre alguns critérios próprios do jornalismo e que, no nosso entender, dialogam com as demandas de pesquisa sobre mediação da informação, conforme abordados pela Cl. Dentre esses aspectos, podemos citar os critérios de noticiabilidade, que definem a relevância dos fatos a serem noticiados; a orientação editorial dos jornais, que norteia 0 valor-notícia em função dos interesses sociais e da empresa de comunicação jornalística; os processos de produção de notícias e suas relações com a opinião pública, onde pode se encontrar as demandas de notícias dos jornais, entre outros que não cabem neste artigo.

A fim de levantar chaves de leitura sobre os tipos de mediações capazes de se relacionar aos fenômenos jornalísticos em tempos de desinformação e pós-verdade, este trabalho defende a mediação da informação conforme apresentada pela $\mathrm{Cl}$ como importante para essa empreitada.

No campo da Comunicação e da Ciência da Informação, além do entendimento das práticas de interação, o conceito de mediação é essencial para entendermos esse momento de instabilidades informacionais e das mudanças nos contextos de informação pelas quais a sociedade está passando. $O$ frisson de trocas informacionais e de compartilhamentos descuidados presentes no âmbito das redes sociais mostram que as pessoas não querem apenas receber a informação. Elas buscam produzir, disseminar e compartilhar conteúdos feitos por outros. E é nesse fluxo menos dominado pelas empresas de jornalismo, onde há mais informação e um menor controle das narrativas, que o cenário para a disseminação em larga escala das notícias falsas é construído.

O presente estudo vem demonstrando como a mediação da informação é um conceito importante quando se busca combater a desinformação em tempos de pós-verdade. A checagem de notícias é analisada neste artigo como uma instância mediacional por excelência. Ela busca as informações compartilhadas pelas redes sociais, detalha ao leitor como investigou o fato noticiado, quantas entrevistas fez e o passo a passo da busca pela informação correta. E devolve ao leitor um diagnóstico sobre o fato. Esse diagnóstico já se apresenta mediacional, na medida em que põe em evidência os contornos da notícia tal 
qual entendida pelo jornalismo e o modo diferente como o ato de "noticiar" é feito pelas redes sociais fora dos escopos jornalísticos. Além de mostrar se o conteúdo é realmente falso e como ele foi construído para enganar o leitor.

No que concerne aos aspectos mais gerais da interação, a relação da informação nas redes com aquela empreendida pelos jornais, há uma via de mão dupla, um caminho percorrido do veículo para a audiência e da audiência para os veículos de comunicação. E tudo regido, principalmente pela interação. É uma rede contínua e coletiva. A palavra interação é descrita como relação, diálogo, contato, inter-relação, comunicação. Um conceito que remete ao comportamento humano de se relacionar socialmente. É um novo momento e deve-se olhar com atenção seja para a área da Comunicação, seja para a área da Ciência da Informação.

Para Ferrara (2015, p. 7), no âmbito da Comunicação "o domínio da mediação caracteriza uma comunicação que se padroniza como código e mensagem a se irradiar de um emissor para um receptor unidimensional". Nela se evidencia o papel dos códigos e suportes e nós diríamos também o realce do papel unilinear do emissor, contrário ao que acontece hoje com os emissores das redes sociais, que deixaram de ser meramente receptores. Em outro aspecto, "o domínio da interação caracteriza uma comunicação que se homologa como possibilidade ou tentativa incerta do comunicar". (FERRARA, 2015, p. 14). Para a autora, ambas são instáveis, posto que é na fronteira de ambas que os atos comunicativos se dão.

Já para a $\mathrm{Cl}$, convém realçar que ela trabalha com o entendimento da informação como fluxo e, nesse sentido, chega-se à noção de mediação da informação, que não pode ser definida como uma ponte entre a informação e os usuários, mas como uma ação de diálogo entre as partes. Mediação significa ação de auxiliar como intermediário entre indivíduos ou grupo de pessoas. A palavra pode ser definida também como "estar no meio", "entre" (ALMEIDA JÚNIOR, 2009). Ele sintetiza a mediação como:

Toda ação de interferência - realizada pelo profissional da informação -, direta ou indireta; consciente ou inconsciente; singular ou plural; individual ou coletiva; que propicia a apropriação de informação que satisfaça, plena ou parcialmente, uma necessidade informacional (ALMEIDA JÚNIOR, 2009, p. 
92).

No entanto, defendemos a ideia de que a "ação de interferência" pode ser uma ação cultural que foque no diálogo das emissões e das recepções pelo complexo sistema cultural que está em curso na dinâmica de trocas entre receptor e emissor, entre mensagem/informação e duas complexas demandas.

A cultura é o processo através do qual o homem cria o algo onde antes imperava o nada. Esse algo é toda complexidade de criações simbólicas, de sentidos e significados que damos às coisas e ao mundo. Um "algo" que não se sustenta se não se entender os processos culturais como mecanismos de mediação entre nós e os fenômenos. Assim, mais do que apenas um elemento da comunicação, a mediação é, por excelência, cultural. As diversas modalidades de mediação são apenas sotaques diferenciados dessa mediação cultural. Assim é a mediação informacional (FEITOSA, 2016, p. 102).

Essa acepção tem base nos estudos antropológicos da cultura, que entendemos ser a base das ações humanas, preponderantemente culturais. Em outras palavras, a metáfora do "algo" onde antes imperava o "nada" deve ser entendida como a mais primeva das mediações: a mediação cultural, que antecede a todas as mediações, notadamente a mediação da informação em contextos sociais que, por natureza, é cultural. Portanto, mesmo como ato de interferência física, o ato mediacional da informação é primordialmente, uma mediação cultural, para só depois ser mediação informacional.

$\mathrm{Na} \mathrm{Cl}$, o que embasa a teoria da mediação da informação é o paradigma social da informação, que a entende à luz dos seus fluxos e das relações socioculturais que estabelecem com os sujeitos. Isso realça que estes veem a informação, interagem e se relacionam com ela, a percebem e a interpretam segundo seus códigos culturais, à luz dos seus repertórios culturais. Assim, para a Cl, a mediação da informação deve ser entendida mais como um movimento entre as partes e não como uma ponte. Logo, a ferramenta de checagem de notícias, que começa a ser utilizada pelo jornalismo a partir da epidemia de notícias falsas, deve ser entendida como um instrumento criado a partir das ações de mediação, quando há essa movimentação de informações entre as áreas envolvidas. $\mathrm{E}$, mais que isso, um processo ativo, quando há ação de todas as partes implicadas. A mediação da informação deixa de ser uma ponte entre duas pessoas, por exemplo, para ser definida como um fluxo de informação que 
se constrói entre as partes no processo, um diálogo. Conceito importante que se torna base das ações realizadas pelo jornalismo ao promover a checagem de notícias como ferramenta de combate às fake news.

O que vimos buscando neste artigo é demonstrar como o jornalismo vem se adaptando aos novos tempos, adquirindo ferramentas e se preocupando em destacar o compromisso com a verdade e como ele se posiciona hoje na busca por uma sociedade mais justa e democrática, tomando por bases os princípios, meios e métodos da mediação da informação, nos moldes como ela é pensada na Comunicação e na Ciência da Informação.

Mais do que uma análise sobre o comportamento da informação em tempos de pós-verdade, faz-se necessário, pela mediação da informação, trazer para o debate possibilidades mediacionais da informação para envolver os profissionais do jornalismo e os profissionais da informação na discussão e apresentação de saídas para mediar os indivíduos e as audiências impactados com as ações problemáticas no trânsito de fluxos informacionais, com a informação que recebem, que compartilham, mas também produzem notadamente no uso das mídias sociais.

É, nesse sentido, que realçamos o papel da informação em suas redes de fluxos informacionais e de como a mediação da informação - tanto para o jornalismo, quanto para os demais sistemas de difusão, circulação e compartilhamento de informações - é importante e merece estar nas discussões contemporâneas sobre os processos de informação jornalística, porque informação também é uma ação que possibilita conhecimento e entendemos que as adversidades decorrentes desses processos de desinformação no jornalismo precisam de mediações.

\section{CAMINHO METODOLÓGICO}

Esta é uma pesquisa exploratória, porquanto estamos aprofundando os estudos teóricos e conceituais da Ciência da Informação e Ciências da Comunicação, os estudos sobre mediação da informação e processos de interação, além dos estudos do jornalismo contemporâneo e das redes sociais, notadamente os conceitos de compartilhamento, com vistas a entender também 
teoricamente os conceitos e processos de pós-verdade, desinformação, fake news e infodemia.

A pesquisa bibliográfica é o que vem subsidiando o estado da arte sobre as questões presentes na pesquisa. A revisão da literatura sobre as principais teorias que norteiam esse trabalho é utilizada como chaves de leitura para aferir aspectos vários dos fenômenos em lide: jornalismo, redes sociais, pós-verdade e fake news, sites de checagem e mediação da informação.

Focada nas relações entre as redes sociais e o compartilhamento de fakes e afins, esta pesquisa debruça-se sobre as ações de um portal de checagem de notícias e a análise de seus conteúdos, explora o seu uso pelo jornalismo e analisa nessas relações os instrumentos e as formas de mediação da informação necessárias à produção jornalística nesses tempos de pós-verdade, de profusão de fake News e afins como ferramentas poderosas para combater a desinformação e levar um selo de credibilidade para as organizações.

Estamos trabalhando com o Projeto Comprova, específico para a checagem de notícias viralizadas, e a metodologia para isso parte da análise de conteúdo, a mesma utilizada por jornalistas, quando estes se acham diante da divulgação viralizadas de notícias pelas redes sociais. A partir disso, uma equipe de jornalistas faz uma investigação profunda a partir de diversas fontes para explicar o que é verdade e o que é mentira.

Os instrumentos dos sites de checagem de notícias para identificar se a notícia é real, parcialmente verdadeira ou falsa são analisados por nós com vistas a entender o que de mediação da informação existe neles e nos seus procedimentos de investigação. Para aclarar epistemologicamente o conceito e uso da mediação, vem sendo feito um estudo comparativo do conceito nos campos da Comunicação e da Ciência da Informação, para ratificar o uso mediacional deste.

\section{O PROJETO COMPROVA E AS CHECAGENS DE NOTÍ́CIAS}

Tomar conhecimento e compartilhar informações sobre diversos assuntos virou moeda na sociedade atual. Na ânsia de se mostrar capaz, por dentro das notícias no cenário de domínio das redes sociais, boa parte das ações desses 
sujeitos atua no compartilhamento de notícias falsas, o que acontece em grandes proporções. E é dentro desta nova normalidade das relações da comunicação que a mediação da informação tem um papel importante em relação ao jornalismo. Diversos sites de notícias e projetos específicos relacionados à checagem de notícias foram criados justamente para travar essa interação com o leitor e prestar um serviço relevante para a contemporaneidade: mostrar o que é verdade e o que é mentira.

Esses portais de checagem de notícias têm a função de conferir e mostrar para o leitor se as informações viralizadas pelas redes sociais são realmente verdadeiras, parcialmente reais ou totalmente enganosas, por exemplo. São diversas as agências que passaram a prestar esse serviço como a Agência Lupa (LUPA..., 2021), Fato ou Fake do Grupo Globo (G1..., 2021), Agência Pública (A PÚBLICA..., 2021) e sites como e E-Farsas (E-FARSAS..., 2021). É nesse contexto que atuam as ações mediacionais dos critérios de notícias, realçados na seção 3.

A presente pesquisa mostra que no Brasil, 33 veículos de comunicação se associaram ao Projeto Comprova (PROJETO..., 2021a) de checagem de notícias, um dos mais importantes programas de combate à fake news do País. Por conta de sua abrangência, a pesquisa o escolheu como o objeto a ser analisado. O objetivo, como destacado no site da instituição (PROJETO..., 2021a), é "identificar e enfraquecer as sofisticadas técnicas de manipulação e disseminação de conteúdo enganoso que vemos surgir em sites, aplicativos de mensagens e redes sociais". A partir de critérios como rigor, integridade, imparcialidade, independência, transparência e responsabilidade ética, uma equipe de jornalistas de todo o Brasil se une para checar informações divulgadas e, principalmente, compartilhadas à exaustão nas redes sociais. Esses critérios são importantes para esta pesquisa pois é a partir deles e de seus usos que vimos analisando onde estão e quais são as marcas da mediação da informação, nos termos em que a Ciência da Informação o concebe, o que tem apresentado muito fatores importantes da mediação da informação no contexto do jornalismo, onde atuamos, como tratados na seção anterior sobre o frisson de trocas informacionais e os compartilhamentos desconexos da realidade pelas redes 
sociais.

Após as análises sobre os fatos, o projeto define o conteúdo como enganoso (conteúdo retirado do contexto original e usado em outro de modo que seu significado sofra alterações; que usa dados imprecisos ou que induz a uma interpretação diferente da intenção de seu autor), falso (inventado ou que tenha sofrido edições para mudar o seu significado original e divulgado de modo deliberado para espalhar uma mentira), sátira (memes, paródias e imitações publicadas com intuito de fazer humor, é verificado quando se percebe que há pessoas tomando-os por verdadeiros) e comprovado (fato verdadeiro; evento confirmado; localização comprovada; ou conteúdo original publicado sem edição). Estes são os procedimentos adotados pelo projeto Comprova. Cada iniciativa decide como definirá as notícias que serão analisadas pela sua equipe. Note-se aqui a mediação por excelência dessas checagens, como ditos anteriormente. Trata-se de uma diagnóstico mediacional entre o site de checagem e o leitor, confrontando e combatendo as notícias falsas, quase sempre travestidas de "verdade" apenas porque são construídas nas redes sociais com a mesma estrutura discursiva dos processos de noticiabilidade, só que sem a observância da ética jornalística.

Das redes sociais, as mensagens voltam para as redações, onde são analisadas e depois publicadas com a tarja que explicará ao leitor se o teor daquele material é verdadeiro. Um fluxo agora muito diferente do que ocorria antigamente, quando as informações normalmente caminhavam de um emissor a um receptor. Agora, ela vai e volta quantas vezes forem necessárias até se encontrar a informação considerada real. Mais que interação, essa mediação feita pelos sites de checagem geram produção do saber.

Para efeito desta pesquisa, foram escolhidas matérias publicadas em 2021. Por exemplo, em fevereiro, um vídeo, postado no Twitter, mostrava o presidente da Anvisa, Antônio Barra Torres, dizendo que a população corria risco sanitário em relação às vacinas contra a Covid-19. De acordo com a checagem, as imagens do vídeo amplamente compartilhadas foram editadas para fazer parecer que ele estava falando sobre as vacinas já aprovadas. Portanto, o vídeo havia sido editado e retirado de contexto. Além de explicar porque era falsa a 
informação, a matéria (PROJETO..., 2021b) trazia o link para a entrevista completa veiculada na emissora CNN Brasil, em 10 de fevereiro de 2021 (CNN..., 2021). Portanto, a ação jornalística detalhou a informação e ainda explicou para o leitor o passo a passo de como a checagem foi feita. Esse aspecto mediacional realça o que Ferrara disse na seção 3 sobre o papel das fronteiras entre mediação e interação como reveladoras do verdadeiro papel da verdade nos atos comunicativos.

Para deixar mais transparentes as ações realizadas para a checagem da notícia, os repórteres envolvidos nessa mediação explicam ainda o motivo de terem realizado o trabalho em cima desse vídeo: "Apesar de o vídeo verificado ter sido postado por um perfil com menos de 2 mil seguidores, ele foi visualizado 24,8 mil vezes. Dessa forma, por se tratar de um conteúdo importante, a verificação se torna fundamental para esclarecer dúvidas".

Há também matérias publicadas a partir de checagem que confirmam uma informação viralizada. Em maio de 2021, por exemplo, o Comprova publicou uma matéria com o título "São verdadeiros exemplos de países com protocolos para cloroquina e cannabis em tuíte de deputado" (PROJETO..., 2021c, online) . A reportagem segue a mesma linha: conta onde a matéria foi postada, como foi a repercussão, como a equipe verificou a informação, porque o assunto foi investigado. E finaliza com o veredito: "Comprovado, para o Comprova, é um fato verdadeiro; evento confirmado).

Esse processo mostra como a mediação da informação atua a partir da realidade de um mundo da pós-verdade. Nesse sentido, a mediação executada por projetos de checagem, como o Comprova, é uma forma atual de lidar com a desinformação e levar mais segurança para a sociedade. É um fluxo dinâmico de informação utilizado pelo jornalismo para a produção da verdade. O carimbo de uma notícia atestada como real também dá um ar de credibilidade ao veículo que a publicou. A ação mediacional de interferência aqui é dada aqui pelo conceito cultural de verdade e de ética jornalística em oposição à ausência deles nas desinformações em curso nas redes sociais.

A Federação Internacional das Associações e Instituições de Bibliotecária (IFLA, 2021) definiu formas de identificar as notícias falsas e ajudar as pessoas 
a diferenciar a verdade da mentira. Inicialmente, deve-se procurar a fonte daquela notícia, quem disse, quando, onde e qual veículo noticiou. Ler mais que o título da mensagem também é importante. Além disso, é vital checar se os autores são confiáveis, procurar outras fontes que confirmem a informação, estar atento se as suas crenças pessoais não afetam seu julgamento sobre o fato, atentar para erros de português. E o jornalismo encontrou nesse problema uma forma de se mostrar ainda mais necessário para a sociedade. Essas também são marcas que aproximam as ações de checagem aos contextos, procedimentos e práticas de mediação da informação, cujos mapas de relações vimos construindo na nossa pesquisa de mestrado para análise futuras.

A metáfora do "algo" substituindo o "nada" pode ser retomada aqui. A mediação cultural é o ato ou efeito de dar sentido às coisas. A verdade jornalística é o sentido que se espera do jornalismo. Do mesmo modo, a ética do jornalista. O "nada" é a ausência disso nas produções de informações nas e pelas redes sociais voltadas para o fim último de desinformar ou realçar mentiras como verdades absolutas. Assim, mesmo entendendo que os exemplos trazidos aqui são poucos, bem diferente do que vimos fazendo na pesquisa de mestrado, eles são suficientes para realçar o papel da mediação da informação no combate à desinformação em tempos de pós-verdade.

\section{CONSIDERAÇÕES FINAIS}

O mundo das tecnologias se transforma numa rapidez sem precedentes e provoca mudança de comportamento em vários contextos. A sociedade hiperconectada mexe com os paradigmas e traz novas formas de nos relacionarmos com o mundo. É a partir desse momento que a informação se torna, cada vez mais, um importante valor na sociedade. E com esse valor, uma série de mudanças ocorrem quando pensamos na forma como consumimos informação.

Um consumo de comunicação e informação que mudou a lógica tradicional do processo infocomunicacional, pois retirou o foco da emissão e o dividiu com os receptores e os contextos de recepção, que passaram a ter um papel importante na produção e difusão de informações. Somado a isso, a 
profusão de espaços de interação e mediações infocomunicacionais, seus fluxos, as instantaneidades e simultaneidades em que produção e recepção acontecem, assim como os rápidos e caóticos processos de compartilhamento e apropriação de informações. A partir deste entendimento, é determinante destacarmos o conceito de mediação como processo e que se estabelece na tensão e na mudança, mas, sobretudo, como uma instância em que o diálogo e a participação de todos os atores da comunicação e da informação precisam estar envolvidos.

Esta pesquisa defende o papel das questões culturais nesse processo mediacional. Assim, tanto as ações mediacionais da e pela cultura como o entendimento da mediação da informação como requisito cultural apontam que a mediação da informação no contexto do jornalismo e frente às investidas dos processos de desinformação ajudará na reconfiguração cultural e comportamental do jornalismo e isso possibilitará o mesmo para os fenômenos comportamentais sociais no uso responsável das redes sociais.

\section{REFERÊNCIAS}

ALMEIDA JÚNIOR, Oswaldo Francisco de. Mediação da informação e múltiplas linguagens. Pesquisa brasileira em Ciência da Informação, Brasília, v. 2, n. 1, p. 89-103, 2009. Disponível em:

https://www.researchgate.net/publication/277162051_MEDIACAO_DA_INFOR MACAO_E_MULTIPLAS_LINGUAGENS. Acesso em: 12 dez. 2021.

ARAÚJO, Carlos Alberto Ávila. O que é Ciência da Informação. Belo Horizonte: KMA, 2018.

A PÚBLICA: Agência de jornalismo investigativo. Home. 2021. Disponível em: http://apublica.org/. Acesso em: 11 dez. 2021.

ART of the lie: Politicians have always lied. Does it matter if they leave the truth behind entirely?. The Economist, 16 de set. 2016. Disponível em:

https://www.economist.com/weeklyedition/2016-09-10. Acesso em: $10 \mathrm{dez}$. 2021.

CNN novo dia - 10/02/2021. [S. I.; s. n.]. 2021. 1 vídeo (290 min). Disponível em:

https://www.youtube.com/watch?list=PL8cUMXM_077elE3o_UGm7HmkukaU9f QaM\&v=X2ke-DYuySA\&feature=youtu.be. Acesso em: 11 dez. 2021. 
E-FARSAS. Home. 2021. Disponível em: https://www.e-farsas.com/. Acesso em: 10 dez. 2021.

FEITOSA, Luiz Tadeu. Complexas Mediações: transdisciplinaridade e incertezas nas recepções informacionais. Informação em Pauta, Fortaleza, v. 1, n. 1, p. 98-117, jun. 2016. Disponível em:

http://www.periodicos.ufc.br/informacaoempauta/article/view/3064. Acesso em: 12 dez. 2021.

FERRARA, Lucrécia. Comunicação Mediações Interações. São Paulo: Paulus, 2015.

GEERTZ, Clifford. A interpretação das culturas. Rio de Janeiro: LTC, 1989.

G1. Fato ou Fake. 2021. Disponível em: https://g1.globo.com/fato-ou-fake/. Acesso em: 12 dez. 2021.

INTERNATIONAL FEDERATIONS OF LIBRARY ASSOCIATIONS AND INSTITUTIONS (IFLA). Home. 2021. Disponível em: https://www.ifla.org/. Acesso em: 11 dez. 2021.

JENKINS, Henry. A Cultura da Convergência. São Paulo: Aleph, 2009.

LUPA: A primeira agência de fact-checking do Brasil. Folha de São Paulo. Início. 2021. Disponível em: https://piaui.folha.uol.com.br/lupa/. Acesso em: 11 dez. 2021.

ORGANIZAÇÃO PAN-AMERICANA DA SAÚDE (OPAS). Entenda a infodemia e a desinformação na luta contra a Covid-19: kit de ferramentas de transformação digital; ferramentas de conhecimento. 2020. Disponível em: https://iris.paho.org/bitstream/handle/10665.2/52054/FactsheetInfodemic_por.pdf?sequence=14\#: :text=The\%20Lancet\%202020\%20Feb\%3B 395(10225)\%3A676. Acesso em: 11 dez. 2021.

PINHEIRO, Marta Macedo Kerr; BRITO, Vladimir de Paula. Em busca do significado da desinformação. DataGramaZero, [S.I.], v. 15, n. 6, 2014. Disponível em: http://hdl.handle.net/20.500.11959/brapci/8068. Acesso em: 11 dez. 2021.

PROJETO Comprova. Home. 2021a. Disponível em: https://projetocomprova.com.br. Acesso em: 10 dez. 2021.

PROJETO Comprova. Vídeo manipulado deturpa entrevista de presidente da Anvisa para sugerir "risco sanitário grave" na vacinação: Em vídeo postado no Twitter, Antônio Barra Torres aparece dizendo que a população "corre risco sanitário grave", mas as imagens foram editadas para fazer parecer que ele se referia às vacinas já aprovadas. O Povo, 18, fev. 2021b. Disponível em: https://www.opovo.com.br/noticias/checagemopovo/2021/02/18/videomanipulado-deturpa-entrevista-de-presidente-da-anvisa-para-sugerir--riscosanitario-grave--na-vacinacao.html. Acesso em: 11 dez. 2021. 
PROJETO Comprova. São verdadeiros exemplos de países com protocolos para cloroquina e cannabis em tuíte de deputado: No tuíte, ele afirma que quatro países teriam protocolos para cloroquina - China, Venezuela, Cuba e Índia - e mais quatro com protocolos para cannabis medicinal - Estados Unidos, Reino Unido, Alemanha e Israel. O Povo, 31 maio 2021c. Disponível em:

https://www.opovo.com.br/noticias/checagemopovo/2021/05/31/saoverdadeiros-exemplos-de-paises-com-protocolos-para-cloroquina-e-cannabisem-tuite-de-deputado.html. Acesso em: 10 dez. 2021.

SCHNEIDER, Marco. CCI/7: Competência crítica em informação (em 7 níveis) como dispositivo de combate à pós-verdade. In: BEZERRA, Arthur Coelho; SCHNEIDER, Marco; PIMENTA, Ricardo M.; SALDANHA, Gustavo Silva (org.). iKritica: estudos críticos em informação. Rio de Janeiro: Garamond, 2019. p. 73-116.

SANTAELLA, Lucia. Da cultura das mídias à cibercultura: o advento do póshumano. Revista Famecos, Porto Alegre, n. 22. 2003. Disponível em: https://revistaseletronicas.pucrs.br/ojs/index.php/revistafamecos/article/downloa d/3229/2493/. Acesso em: 10 dez. 2021.

SANTAELLA, Lucia. A Pós-Verdade é Verdadeira ou Falsa?. Barueri: Estação das Letras e Cores, 2018.

TRAQUINA, Nelson. Teorias do Jornalismo. Florianópolis: Insular, 2005. volume 2

\title{
MEDIATION: A TOOL AGAINST DISINFORMATION IN POST-TRUTH TIMES
}

\begin{abstract}
Objective: In post-truth times, fake news is gaining more space and is responsible for important and harmful changes in the planet's reality. Facts such as Donald Trump's elections and the Brexit referendum are considered by policy analysts as the beginning of the most forceful way of changing reality from the spread of false news. In Brazil, the 2018 elections were also fraught with disinformation. Based on the Information Science and Communication, this research analyzes how journalism behaves in this new scenario. Methodology: Content analysis and a bibliographical research based on the theories of communication and information. Results: It is demonstrated how the mediation carried out from the fact-check sites are instruments against fake news and the dissemination of misinformation. Conclusions: Fact Checking sites, such as Comprova Project, use the mediation of information and communication as a tool to disseminate truthful information and detail how false news is constructed and easily disseminated by social media.
\end{abstract}

Descriptors: Fake News. Post-truth. Communication. Information. Journalism. 


\section{MEDIACIÓN: UNA HERRAMIENTA CONTRA LA DESINFORMACIÓN EN LA POST-VERDAD}

\section{RESUMEN}

Objetivo: En tiempos posteriores a la verdad, las noticias falsas ganan más espacio y son responsables de cambios importantes y dañinos en la realidad del planeta. Hechos como las elecciones de Donald Trump y el referéndum del Brexit son considerados por los analistas políticos como el comienzo de la forma más contundente de cambiar la realidad a partir de la difusión de noticias falsas. En Brasil, las elecciones de 2018 también estuvieron plagadas de desinformación. A partir de los fenómenos de las Ciencias de la Información y la Comunicación, esta investigación analiza cómo se comporta el periodismo en este nuevo escenario. Metodología: Análisis de contenido e investigación bibliográfica a partir de las teorías de la comunicación y la información. Resultados: Se demuestra cómo las mediaciones realizadas desde los sitios de verificación de noticias son instrumentos para combatir las fake news, contra la difusión de desinformación. Conclusiones: Los sitios de consulta de noticias, como Projeto Comprova, utilizan la mediación de la información y la comunicación como herramienta para difundir información veraz y detallan cómo se construyen y difunden fácilmente las noticias falsas en las redes sociales.

Descriptores: Noticias falsas. Posverdad. Comunicación. Información. Periodismo.

Recebido em: 15.10 .2021

Aceito em: 27.12.2021 